\title{
Akkermansia muciniphila gen. nov., sp. nov., a human intestinal mucin-degrading bacterium
}

\author{
Muriel Derrien, Elaine E. Vaughan, Caroline M. Plugge \\ and Willem M. de Vos \\ Laboratory of Microbiology, Wageningen University, Hesselink van Suchtelenweg 4, 6703 CT \\ Wageningen, The Netherlands
}

Correspondence

Muriel Derrien

muriel.derrien@wur.nl

\begin{abstract}
The diversity of mucin-degrading bacteria in the human intestine was investigated by combining culture and $16 \mathrm{~S}$ rRNA-dependent approaches. A dominant bacterium, strain $\mathrm{Muc}^{\top}$, was isolated by dilution to extinction of faeces in anaerobic medium containing gastric mucin as the sole carbon and nitrogen source. A pure culture was obtained using the anaerobic soft agar technique.

Strain Muc $^{\top}$ was a Gram-negative, strictly anaerobic, non-motile, non-spore-forming, oval-shaped bacterium that could grow singly and in pairs. When grown on mucin medium, cells produced a capsule and were found to aggregate. Strain $\mathrm{Muc}^{\top}$ could grow on a limited number of sugars, including $\mathrm{N}$-acetylglucosamine, $\mathrm{N}$-acetylgalactosamine and glucose, but only when a protein source was provided and with a lower growth rate and final density than on mucin. The $G+C$ content of DNA from strain $\mathrm{Muc}^{\top}$ was 47.6 mol\%. 16S rRNA gene sequence analysis revealed that the isolate was part of the division Verrucomicrobia. The closest described relative of strain Muc $^{\top}$ was Verrucomicrobium spinosum (92\% sequence similarity). Remarkably, the 16S rRNA gene sequence of strain Muc $^{\top}$ showed $99 \%$ similarity to three uncultured colonic bacteria.

According to the data obtained in this work, strain $\mathrm{Muc}^{\top}$ represents a novel bacterium belonging to a new genus in subdivision 1 of the Verrucomicrobia; the name Akkermansia muciniphila gen. nov., sp. nov. is proposed; the type strain is $\mathrm{Muc}^{\top}\left(=\mathrm{ATCC}^{\mathrm{BAA}}-835^{\top}=\right.$ CIP $\left.107961^{\top}\right)$.
\end{abstract}

The human gastrointestinal (GI) tract harbours diverse and abundant microbiota, which have effects on the health and disease of the host due to their close association (Hooper \& Gordon, 2001). A mucus layer covers the GI tract, providing a protective barrier for the underlying epithelium against pathogenic micro-organisms, as well as chemical, physical or enzymic damage. Mucus is a viscous gel mainly composed of high-molecular-mass glycoproteins, termed mucins. Mucins are composed of a peptide core rich in serine and threonine residues that is decorated by oligosaccharides linked via $O$ - or $N$-glycosidic bonds. The oligosaccharides are composed of one or more of four primary sugars ( $N$-acetylglucosamine, $N$-acetylgalactosamine, galactose and fucose) and are terminated by sialic acids or sulfate groups. This mucus layer is considered to be an ecological niche for intestinal microbiota. However, the association of microbiota with the mucus is not well understood. Mucus can serve as a barrier to protect the

Published online ahead of print on 14 May 2004 as DOI 10.1099/ ijs.0.02873-0.

Abbreviations: DGGE, denaturing gradient gel electrophoresis; Gl, gastrointestinal; MPN, most probable number.

The GenBank/EMBL/DDBJ accession number for the 16S rRNA gene sequence of Akkermansia muciniphila Muc ${ }^{\top}$ is AY271254. underlying epithelium from the attachment of pathogens and also as a source of nutrients for commensal bacteria. Degradation of mucin is regarded as a pathogenicity factor since loss of the protective mucus layer may expose GI tract cells to pathogens (Ruseler-van Embden et al., 1995; Zhou et al., 2001). However, mucin also constitutes a carbon and energy source for intestinal microbiota. It has been estimated that $1 \%$ of colonic microbiota is able to degrade host mucin using enzymes (e.g. glycosidases and sulfatases) that can degrade the oligosaccharide chains (Hoskins \& Boulding, 1981). Despite the apparent low level of mucindegrading bacteria, these species provide nutrients for other resident bacteria, which can use the monosaccharides or amino acids released from mucin degradation. Based on their capacity to grow on mucin-containing media, isolates belonging to the genera Ruminococcus, Bacteroides, Bifidobacterium and Clostridium have been shown to degrade mucin (Salyers et al., 1977). By measuring the release of reducing sugar monomers from the mucin polymer, it was observed that only mixed cultures of faecal bacteria were able to degrade mucin by more than $90 \%$, whereas pure cultures of Bacteroides fragilis, Bifidobacterium longum and Clostridium perfringens showed only partial degradation (Willis et al., 1996). It is therefore likely that, in vivo, a cooperative process is required to achieve efficient degradation of the complex structure of mucin. 
The introduction of high-resolution molecular techniques has improved analyses of complex microbial ecosystems. The most important advance has been the use of the $16 \mathrm{~S}$ rRNA gene as a molecular fingerprint to analyse microbial diversity. Molecular approaches have indicated that a lack of knowledge regarding cultivation conditions has hampered our view of the intestinal microbiota (Vaughan et al., 2000). As a consequence, a substantial proportion of the microbiota has not yet been cultured or described (Zoetendal et al., 1998; Suau et al., 1999); this may be due mainly to the lack of appropriate cultivation techniques. However, new, alternative and improved cultivation approaches are continuously being developed and recently a number of novel species and genera have been cultured from the GI tract: Roseburia intestinalis (Duncan et al., 2002), Campylobacter hominis (Lawson et al., 2001), Ruminococcus luti (Simmering et al., 2002), Anaerostipes caccae (Schwiertz et al., 2002), Dorea longicatena (Taras et al., 2002) and Victivallis vadensis (Zoetendal et al., 2003).

In the present study, mucin-degrading bacteria from human faeces were enriched using a most probable number (MPN) approach in which the medium contained mucin as the sole carbon and energy source. The enrichments were analysed by denaturing gradient gel electrophoresis (DGGE) of PCR-amplified 16S rRNA gene sequences. A single DGGE type dominated all the positive MPN enrichments. The organism corresponding to the dominant DGGE type was isolated and characterized; it represents a novel intestinal bacterium, strain $\mathrm{Muc}^{\mathrm{T}}$, that is able to use gastric mucin in pure culture.

A faecal sample from a healthy adult volunteer was freshly collected in a polyethylene bag and $0.5 \mathrm{~g}$ was diluted into $9 \mathrm{ml}$ sterile anaerobic Ringer's solution containing $0.5 \mathrm{~g}$ cysteine $1^{-1}$. This suspension was thoroughly mixed and serially diluted (10-fold) in Ringer's. Each dilution $(1 \mathrm{ml})$ was inoculated in triplicate into $9 \mathrm{ml}$ bicarbonate-buffered medium. This basal medium contained $\left(1^{-1}\right): 0 \cdot 4 \mathrm{~g} \mathrm{KH}_{2} \mathrm{PO}_{4}$; $0.53 \mathrm{~g} \mathrm{Na} \mathrm{Na}_{2} \mathrm{HPO}_{4} ; \quad 0.3 \mathrm{~g} \quad \mathrm{NH}_{4} \mathrm{Cl} ; \quad 0.3 \mathrm{~g} \quad \mathrm{NaCl} ; 0.1 \mathrm{~g}$ $\mathrm{MgCl}_{2} \cdot 6 \mathrm{H}_{2} \mathrm{O} ; 0 \cdot 11 \mathrm{~g} \mathrm{CaCl}_{2} ; 1 \mathrm{ml}$ alkaline trace element solution; $1 \mathrm{ml}$ acid trace element solution; $1 \mathrm{ml}$ vitamin solution; $0.5 \mathrm{mg}$ resazurin; $4 \mathrm{~g} \quad \mathrm{NaHCO}_{3} ; 0.25 \mathrm{~g}$ $\mathrm{Na}_{2} \mathrm{~S} .7-9 \mathrm{H}_{2} \mathrm{O}$. The trace element and vitamin solutions were as described previously (Stams et al., 1993). All compounds were autoclaved, except the vitamins, which were filter-sterilized. This basal medium was supplemented with $0.7 \%(\mathrm{v} / \mathrm{v})$ clarified, sterile rumen fluid and $0.25 \%(\mathrm{v} / \mathrm{v})$ commercial hog gastric mucin (Type III; Sigma), purified by ethanol precipitation as described previously (Miller \& Hoskins, 1981). This medium is further referred to as mucin medium. Unless indicated, incubations were done in serum bottles sealed with butyl-rubber stoppers at $37^{\circ} \mathrm{C}$ under anaerobic conditions provided by a gas phase of $182 \mathrm{kPa}(1 \cdot 8 \mathrm{~atm}) \mathrm{N}_{2} / \mathrm{CO}_{2}(80: 20$, v/v). Enrichments were done in $30 \mathrm{ml}$ serum bottles with $10 \mathrm{ml}$ liquid volume. Negative controls comprised one series of mucin media that was not inoculated and another series that was inoculated, but not supplemented with mucin. Mucindegrading bacteria were quantified using the MPN technique $(n=3)$. The soft agar technique was used to isolate a pure culture as follows: the highest dilution where growth was observed was serially diluted in phosphate buffer ( $\mathrm{pH} 7$ ) until $10^{-9}$ dilution and the $10^{-6}$ to $10^{-9}$ dilutions were re-inoculated into the same medium containing $0.75 \%$ agar (agar noble; Difco). Single colonies were picked, grown in mucin medium and re-inoculated in soft agar mucin medium. This step was repeated until purity.

Generation times were determined in mucin medium and growth was analysed in triplicate by measuring absorbance at $600 \mathrm{~nm}$. The optimum $\mathrm{pH}$ and temperature were measured in triplicate on brain-heart infusion (BHI; Difco) supplemented with $1 \mathrm{mM} \mathrm{Na}_{2} \mathrm{~S}$. Temperatures tested were $4-45^{\circ} \mathrm{C}$, at intervals of $5{ }^{\circ} \mathrm{C}$; growth was determined at $\mathrm{pH} 5-9$, at intervals of $0.5 \mathrm{pH}$ units (adjusted with $\mathrm{HCl}$ or $\mathrm{NaOH})$ at $37^{\circ} \mathrm{C}$. Cultures were incubated for at least 1 month.

Potential substrates for growth were tested at a concentration of $10 \mathrm{mM}$ in the same liquid basal medium or in basal medium supplemented with peptone, tryptone, casitone and yeast extract at a concentration of 0.5 or $2 \mathrm{~g} \mathrm{l}^{-1}$. Cultures were incubated for up to 4 weeks. Human gastric mucin was isolated from HT-29 MTX human intestinal cell lines and this mucin was added to the basal liquid medium at a concentration of $0.05 \%$. Rich media BHI and Columbia broth (Difco) and $16 \mathrm{~g}$ Wilkens-Chalgren broth (WC broth; Oxoid) $1^{-1}$ were also tested as growth substrates. To test the origin of the nitrogen source, the solution containing $\mathrm{NH}_{4} \mathrm{Cl}$ was not added to the mucin medium.

Cell morphology, motility and spore formation were investigated using phase-contrast microscopy. The Gram reaction was assessed using Gram staining as described previously (Plugge et al., 2000). To test for the presence of a capsule, an Indian ink suspension was used.

For TEM of strain $\mathrm{Muc}^{\mathrm{T}}$, cells were fixed with $0.25 \%$ glutaraldehyde. Negative staining was performed on 400 copper mesh grids with glow-discharged parladion carbonsupport film. Micrographs were recorded at a magnification of $40000 \times$ on a JEOL 1010 electron microscope operating at $80 \mathrm{kV}$. For SEM, droplets of strain $\mathrm{Muc}^{\mathrm{T}}$ were put onto poly-L-lysine-coated Nucleopore polycarbonate membranes (Costar). These membranes were fixed for $1 \mathrm{~h}$ in $4 \%$ glutaraldehyde in growing medium. Specimens were dehydrated in a graded series of ethanol and critical-point dried with carbon dioxide. The samples were glued onto a sample holder using carbon adhesive tabs. Samples were sputter-coated with $10 \mathrm{~nm}$ platinum in a dedicated preparation chamber (CT $1500 \mathrm{HF}$ ) and analysed with a field emission SEM (JEOL $6300 \mathrm{~F}$ ) at $5 \mathrm{kV}$.

The $\mathrm{G}+\mathrm{C}$ content of DNA of strain Muc ${ }^{\mathrm{T}}$ was determined 
at the DSMZ (Deutsche Sammlung von Mikroorganismen und Zellkulturen, Braunschweig, Germany) by HPLC (Mesbah et al., 1989).

To monitor the dynamics of the human faecal mucindegrading population, DGGE analysis of $16 \mathrm{~S}$ rRNA gene amplicons was performed. DNA was extracted from the faecal sample, enrichment cultures and a pure culture isolated from the highest dilution. DNA isolation and the amplification of the V6 to V8 regions of the 16S rRNA gene from these samples were performed as described previously (Zoetendal et al., 1998). PCR fragments were separated by DGGE consisting of $8 \%(\mathrm{v} / \mathrm{v})$ polyacrylamide (ratio of acrylamide to bisacrylamide, $37 \cdot 5: 1$ ) and $0 \cdot 5 \times$ Tris/acetate/EDTA (pH 8.0) (TAE) buffer; $100 \%$ denaturing acrylamide was defined as $7 \mathrm{M}$ urea and $40 \%$ formamide. Gradients of $38-48 \%$ were used to separate products amplified with universal primers. After migration of the PCR products at $85 \mathrm{~V}$ for $16 \mathrm{~h}$, the gels were stained with $\mathrm{AgNO}_{3}$ as described previously (Sanguinetti et al., 1994).

PCR on the 16S rRNA gene of strain Muc ${ }^{\mathrm{T}}$ was performed with universal primers $11 \mathrm{f}$ and 1510r (Lane, 1991). The following PCR programme was used: $94{ }^{\circ} \mathrm{C}$ for $5 \mathrm{~min} ; 40$ cycles consisting of $94^{\circ} \mathrm{C}$ for $1 \min 30 \mathrm{~s}, 48^{\circ} \mathrm{C}$ for $30 \mathrm{~s}$, and $68^{\circ} \mathrm{C}$ for $1 \mathrm{~min} 30 \mathrm{~s}$; and finally $68^{\circ} \mathrm{C}$ for $7 \mathrm{~min}$. PCR products were purified and concentrated with the Qiaquick PCR purification kit (Qiagen) according to the manufacturer's instructions. The purified 16S rRNA gene product was sequenced on both strands using infrared Dye 41labelled primers 7f, 342r, 805f, 1100r and 1510r (Lane, 1991), and 968f (Nübel et al., 1996). One extra primer, Muc1 (5'-GGA AAC CCT GAT GGT GCG-3'), which targets a $339 \mathrm{bp}$ specific region of the 16S rRNA gene sequence of strain $\mathrm{Muc}^{\mathrm{T}}$, was designed to obtain unambiguous results. Sequences were automatically analysed on a LI-COR DNA sequencer 4000L and corrected manually. Pairwise sequence alignment was performed with the program DNASTAR. The $16 \mathrm{~S}$ rRNA gene sequence was compared to sequences from GenBank using the program BLASTN 2.0, available through the National Centre for Biotechnology Information (NCBI) website (http://www. ncbi.nlm.nih.gov/blast/). The ARB software package was used to align cloned sequences and 16S rRNA gene sequences of nearest relatives (Strunk \& Ludwig, 1995). A phylogenetic tree was constructed with ARB using the neighbour-joining method. The distance matrix used in the neighbour-joining method included stretches of sequence corresponding to Escherichia coli positions 63-1491.

Substrates and fermentation product concentrations were determined in the culture before and after growth using HPLC and GC methods as described previously (Stams et al., 1993).

The use of serial dilution in an anaerobic medium containing mucin as energy source led to the isolation of a predominant mucin-degrading bacterium from the human

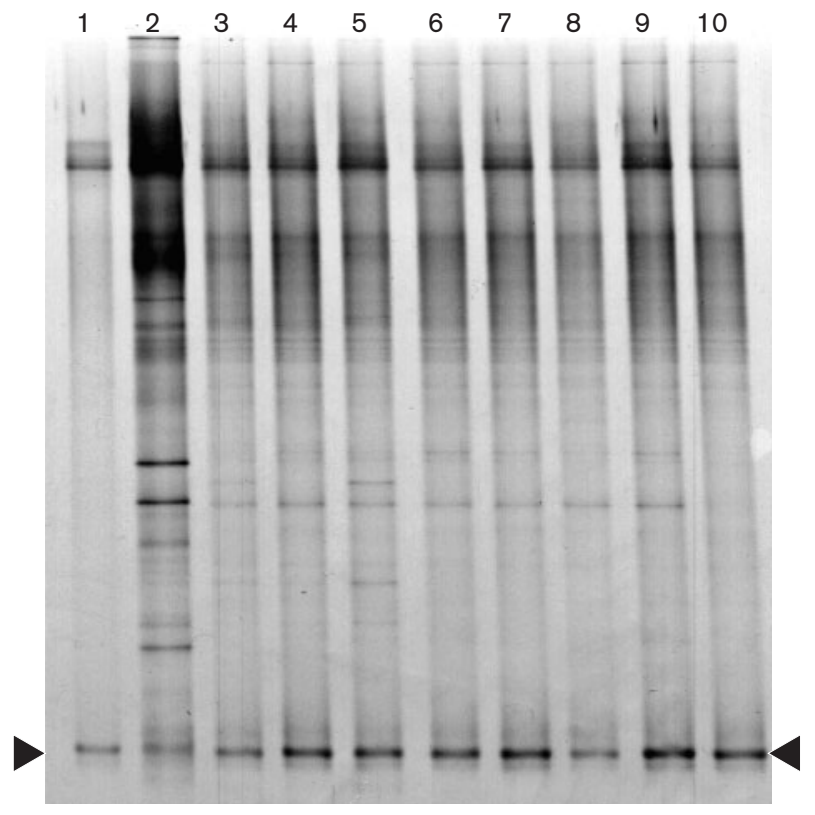

Fig. 1. DGGE profiles of the $V 6$ to $V 8$ regions of $16 S$ rRNA gene from strain $\mathrm{Muc}^{\top}$ (lane 1), faecal sample (lane 2) and dilution $10^{-2}$ to $10^{-9}$ of the enrichment of faecal bacteria in mucin medium (lanes 3-10). The arrowheads indicate the migration position of the 16S rRNA gene amplicon of strain $\mathrm{Muc}^{\top}$.

faecal sample. As in all MPN studies, the low-dilution cultures presumably gave rise to the fastest-growing organisms under the given culture conditions, whereas the highdilution cultures supported growth of the numerically dominant organisms. In our study, a single band generated by PCR-DGGE (Fig. 1) dominated all dilutions, indicating that there was one predominant mucin-degrading bacterium and that this was also the fastest-growing mucindegrading organism. The MPN of mucin-degrading organisms present in this faecal sample was estimated at

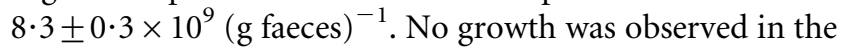
uninoculated mucin medium, indicating the sterility of the mucin, nor in the medium inoculated with faecal dilutions but not supplemented with mucin. This indicates that growth occurred solely due to utilization of mucin by the faecal bacteria.

Microscopic analysis of the enrichment dilutions revealed that an oval-shaped organism was predominant in the first dilutions of the enrichment. The 16S rRNA gene amplicons from all the dilutions of the enrichment where growth was observed $\left(10^{-2}\right.$ to $\left.10^{-9}\right)$ were analysed by DGGE (Fig. 1, lanes 3-10). In the first dilutions, many bands were detected, but one was predominant. This band became more intense with increasing dilution and, in the highest dilution where growth occurred $\left(10^{-9}\right)$, this band was almost unique in the profile. The faecal sample profile showed a band at the same position, suggesting that the enriched micro-organism 
containing this $16 \mathrm{~S}$ rRNA gene is the same as the one present in the faecal sample and represents at least $1 \%$ of the total intestinal bacterial community (Muyzer et al., 1993). The mucin-degrading bacterium, whose $16 \mathrm{~S}$ rRNA gene corresponded to the major DGGE band present in the enrichment (lane 10), was cultured from the highest dilution with growth $\left(10^{-9}\right)$ using the soft agar technique. After 6 days, the most predominant colony type, white, was grown in the mucin medium. White colonies were picked, diluted in the mucin medium and transferred into soft agar mucin medium. This purification step was repeated twice. Finally, a single type of white colony appeared. Phase-contrast microscopy revealed only one morphotype, and the DGGE profile of the 16S rRNA gene amplicon of the strain isolated showed the presence of a unique band corresponding to the major band present in the enrichment (Fig. 1, lane 1). The pure culture was designated strain $\mathrm{Muc}^{\mathrm{T}}$.

An almost-complete $16 \mathrm{~S}$ rRNA gene sequence of strain Muc $^{\mathrm{T}}$ was determined (1433 bp). The most similar $16 \mathrm{~S}$ rRNA gene sequences, which were derived from studies of uncultured colonic bacteria [HuCA18 and HuCC13 (Hold et al., 2002) and L10-6 (Salzman et al., 2002)] were 99\% identical to strain $\mathrm{Muc}^{\mathrm{T}}$. The cultured bacterium most closely related to strain $\mathrm{Muc}^{\mathrm{T}}$ was Verrucomicrobium spinosum, and this was only distantly related (92\%). A phylogenetic dendrogram based on $16 \mathrm{~S}$ rRNA gene sequences was constructed; it revealed that strain $\mathrm{Muc}^{\mathrm{T}}$ is related to the genera Prosthecobacter and Verrucomicrobium, which are members of the order Verrucomicrobiales. Thus,
Muc $^{\mathrm{T}}$ belongs to the division Verrucomicrobia and the class Verrucomicrobiae (Fig. 2). The majority of the members of this new division are clones and only a few are cultivated bacteria: a single genus, Verrucomicrobium (Schlesner, 1987), after which the division was named; four species of the genus Prosthecobacter (Prosthecobacter debontii, Prosthecobacter dejongeii, Prosthecobacter fusiformis and Prosthecobacter vanneervenii) (Staley et al., 1976; Hedlund et al., 1997); Opitutus terrae (Chin et al., 2001) and other ultramicrobacteria (Janssen et al., 1997); and the recently described species Victivallis vadensis, the first member of the division Verrucomicrobia to be isolated from the GI tract (Zoetendal et al., 2003). Members of the 'Verrucomicrobium' group of bacteria have also been identified in low numbers in human faeces-derived $16 \mathrm{~S}$ rRNA gene libraries (Wilson \& Blitchington, 1996; Suau et al., 1999; Hold et al., 2002). The division Verrucomicrobia is composed of five subdivisions (Hugenholtz et al., 1998) and the genera Prosthecobacter and Verrucomicrobium are part of subdivision 1. Bacteria from these two genera were isolated from freshwater habitats and are both Gram-negative, aerobic and heavily fimbriated. Cells of Verrucomicrobium have many prosthecae, whereas cells of Prosthecobacter have only a single prosthecae. Strain $\mathrm{Muc}^{\mathrm{T}}$ shares some common characteristics; for example, it is Gram-negative and can grow without vitamins. However, strain $\mathrm{Muc}^{\mathrm{T}}$ is distinct among the members of subdivision 1 in that it is strictly anaerobic and cells are oval-shaped in contrast to the other members (see Table 1). On the basis of a phylogenetic analysis, strain $\mathrm{Muc}^{\mathrm{T}}$ does not belong to the Verrucomicrobium or Prosthecobacter clusters and

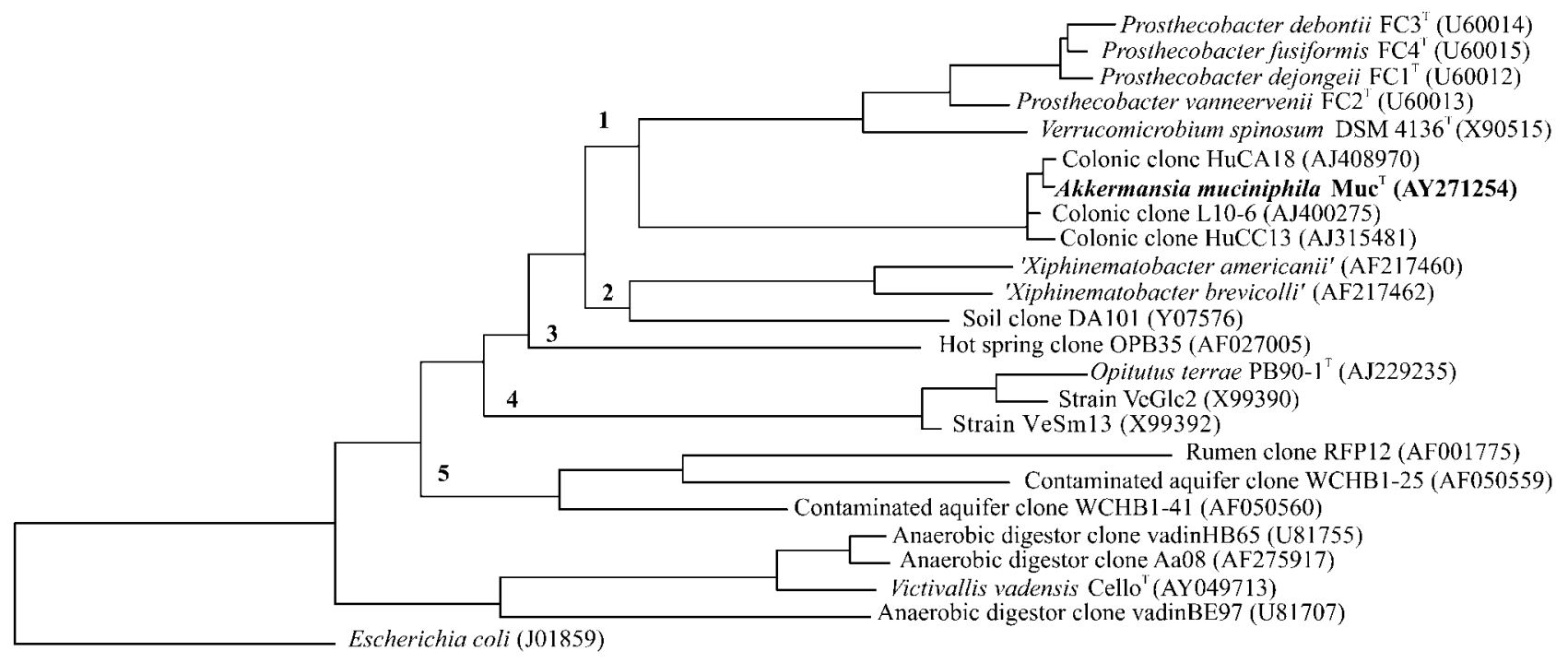

$0 \cdot 10$

Fig. 2. Phylogenetic tree showing the position of strain $\mathrm{Muc}^{\top}$ among selected clones or strains belonging to the division Verrucomicrobia. The tree, which was rooted using Escherichia coli as the outgroup, was generated by the neighbour-joining method. The numbers before the interior branch points indicate the five major lineages within the division Verrucomicrobia as proposed by Hugenholtz et al. (1998). Bar, $10 \%$ sequence divergence. 
Table 1. Characteristics that differentiate the genus Akkermansia from other genera of the subdivision 1 of the division Verrucomicrobia

Data taken from Schlesner (1987), Hedlund et al. (1997), Staley et al. (1976). +, Positive; -, negative; W, weakly positive; ND, not determined. 1, strain $\mathrm{Muc}^{\mathrm{T}}$; 2, Verrucomicrobium (based on Verrucomicrobium spinosum); 3, Prosthecobacter (based on P. debontii, P. dejongeii, P. fusiformis and P. vanneervenii). All genera are negative for motility, a requirement for vitamins, and growth on amino acids and other organic acids. All genera are sensitive to ampicillin.

\begin{tabular}{|c|c|c|c|}
\hline Characteristic & 1 & 2 & 3 \\
\hline Cell morphology & Oval-shaped & Fusiform rod-shaped & Fusiform rod-shaped \\
\hline Cell size $(\mu \mathrm{m})$ & $0 \cdot 6-1 \cdot 0$ & $0 \cdot 8-1 \cdot 0 \times 1 \cdot 0-3 \cdot 8$ & $0 \cdot 5 \times 2 \cdot 0-8 \cdot 0$ \\
\hline Temperature range for growth $\left({ }^{\circ} \mathrm{C}\right)$ & $20-40$ & $26-34$ & $1-40$ \\
\hline Prosthecate & - & + & + \\
\hline \multicolumn{4}{|l|}{ Growth on: ${ }^{*}$} \\
\hline Glucose & $\mathrm{w} \dagger$ & + & + \\
\hline Galactose & - & + & + \\
\hline Fructose & - & + & $+1-末$ \\
\hline Cellobiose & - & + & + \\
\hline
\end{tabular}

${ }^{*}$ Growth was determined by measuring $\mathrm{OD}_{600}$ in basal medium supplemented with the appropriate substrate (10mM final concentration; see text).

$\dagger$ When a protein source is provided (peptone, yeast extract, tryptone and casitone at final concentration of $2 \mathrm{~g} 1^{-1}$ each).

$\ddagger$ Depends on species.

should be considered as a separate phylogenetic branch. It is therefore proposed that strain $\mathrm{Muc}^{\mathrm{T}}$ represents a novel species in a new genus belonging to subdivision 1 of the Verrucomicrobia.

Strain $\mathrm{Muc}^{\mathrm{T}}$ is an obligate chemo-organotroph. No growth was detected on basal medium supplemented with vitamins and purged with $\mathrm{H}_{2} / \mathrm{CO}_{2}(80: 20)$. Rumen fluid and vitamins were not required for growth on mucin and, for further characterization of the strain, they were not added to the mucin medium. Growth was not observed in mucin medium in the absence of a reducing agent, as indicated by the pink colour of the medium, demonstrating the strict anaerobic nature of strain $\mathrm{Muc}^{\mathrm{T}}$. The isolate could grow between 20 and $40{ }^{\circ} \mathrm{C}$, with optimum growth at $37^{\circ} \mathrm{C}$. The optimum $\mathrm{pH}$ for growth was $6 \cdot 5$. No growth was observed below $\mathrm{pH} 5 \cdot 5$ or above $\mathrm{pH}$. The doubling time of the strain was approximately $1.5 \mathrm{~h}$ in mucin medium.

No growth was observed on glucose, cellobiose, lactose, galactose, xylose, fucose, rhamnose, maltose, succinate, acetate, fumarate, butyrate, lactate, casitone $(0.5 \%)$, Casamino acids $(0.5 \%)$, tryptone $(0.5 \%)$, peptone $(0.5 \%)$, yeast extract $(0.5 \%)$, proline, glycine, aspartate, serine, threonine, glutamate, alanine, $\mathrm{N}$-acetylglucosamine or $\mathrm{N}$-acetylgalactosamine after 4 weeks incubation. Gastric mucin isolated from human intestinal cell lines and adapted on $10^{-5} \mathrm{M}$ methotrexate (HT-29 MTX) to produce a high amount of mucin (Lesuffleur et al., 1990) resulted in growth of strain $\mathrm{Muc}^{\mathrm{T}}$ to the same density as with hog gastric mucin. Strain $\mathrm{Muc}^{\mathrm{T}}$ could also grow on rich media, Columbia and BHI, but with a final optical density of half that of the mucin medium. No growth was observed on rich WC anaerobe broth. When peptone, yeast extract, tryptone and casitone (each at $2 \mathrm{~g} \mathrm{l}^{-1}$ ) were added to the basal medium, growth was observed only when the sugars $\mathrm{N}$-acetylglucosamine, $\mathrm{N}$-acetylgalactosamine and glucose were added, although bacterial growth was less than a quarter of that on mucin medium. When the solution containing the nitrogen source was not added to the basal medium supplemented with mucin, strain $\mathrm{Muc}^{\mathrm{T}}$ could grow to the same density, indicating that the isolate utilized mucin as both carbon and nitrogen source. Strain $\mathrm{Muc}^{\mathrm{T}}$ did not produce $\mathrm{H}_{2}$, but acetate, propionate and ethanol were formed from mucin fermentation. No sulfides were produced. Sulfates were released during fermentation of mucin $(0.71 \mathrm{mM})$, demonstrating sulfatase activity. It is presumed that the limited ability of strain $\mathrm{Muc}^{\mathrm{T}}$ to grow on the many substrates tested may be due to the complex structure of the mucin, which is composed of both oligosaccharides and amino acids, and that strain $\mathrm{Muc}^{\mathrm{T}}$ requires a combination of all these components to reach a high density. It is likely that strain $\mathrm{Muc}^{\mathrm{T}}$ produces one or more 

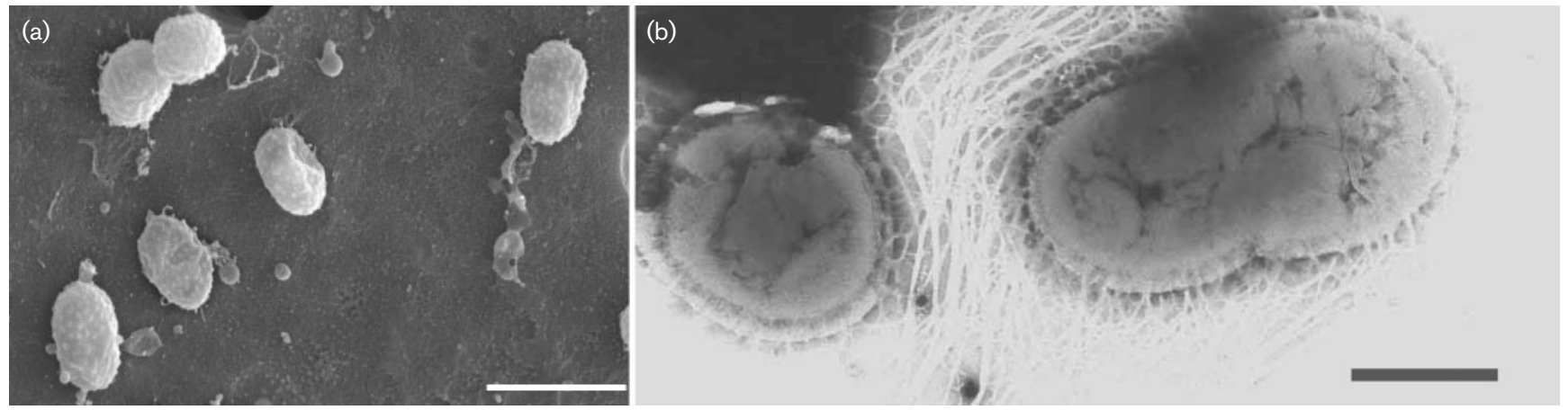

Fig. 3. EM images of strain Muc ${ }^{\top}$. (a) SEM image. Bar, $1 \mu \mathrm{m}$. (b) TEM image of a negatively stained preparation. Note the thickened but extensive capsule fibres of the cells. Bar, $0.5 \mu \mathrm{m}$.

appropriate glycosidases to degrade the $N$-acetylgalactosamine and $\mathrm{N}$-acetylglucosamine components from mucin, which might be exposed in the terminal part, and to use them as growth substrates.

Cells of strain $\mathrm{Muc}^{\mathrm{T}}$ were oval-shaped (Fig. 3a), showing a different size depending on the medium. In mucin medium, strain $\mathrm{Muc}^{\mathrm{T}}$ was $640 \mathrm{~nm}$ in diameter and $690 \mathrm{~nm}$ in length and in BHI, strain $\mathrm{Muc}^{\mathrm{T}}$ was $830 \mathrm{~nm}$ in diameter and $1 \mu \mathrm{m}$ in length. Cells stained Gram-negative. Flagella were not seen on negatively stained EM preparations. Spore formation was never observed. In mucin medium, the organism could grow as single cells or in pairs, but rarely in chains; it often formed aggregates in which a translucent layer of material was observed between organisms. In BHI and Columbia media, this material was rarely, if ever, observed and cells occurred singly or in pairs, but rarely in groups. In basal medium, supplemented with $\mathrm{N}$-acetylglucosamine or $\mathrm{N}$-acetylgalactosamine, together with some sources of proteins (a combination of yeast extract, peptone, tryptone and casitone), cells occurred singly and sometimes in pairs. Cells of strain $\mathrm{Muc}^{\mathrm{T}}$ grown in mucin medium could exclude Indian ink, which is characteristic of capsule-possessing bacteria. EM revealed the existence of filamentous structures on cells grown in mucin medium (Fig. 3b). It is assumed that these filaments are capsular polymers that are used to connect cells together. Since this aggregation is mainly observed in mucin medium, this capsule may aid in adhesion and colonization of mucin-secreting epithelia in the GI tract. On soft agar medium, colonies of strain $\mathrm{Muc}^{\mathrm{T}}$ appeared white and were $0.7 \mathrm{~mm}$ in diameter.

Based on morphological, physiological and phylogenetic features of strain $\mathrm{Muc}^{\mathrm{T}}$, a new genus, Akkermansia, with the type species Akkermansia muciniphila gen. nov., sp. nov. is proposed.

\section{Description of Akkermansia gen. nov.}

Akkermansia (Ak.ker.man'si.a. N.L. fem. n. Akkermansia derived from Antoon Akkermans, a Dutch microbiologist recognized for his contribution to microbial ecology).
Cells are oval-shaped, non-motile and stain Gram-negative. Strictly anaerobic. Chemo-organotrophic. Mucolytic in pure culture.

The type species is Akkermansia muciniphila.

\section{Description of Akkermansia muciniphila sp. nov.}

Akkermansia muciniphila (mu.ci.ni'phi.la. N.L. neut. n. mucinum mucin; Gr. adj. philos loving; N.L. fem. adj. muciniphila mucin-loving).

Cells are oval-shaped, non-motile and stain Gram-negative. The long axis of single cells is $0 \cdot 6-1 \cdot 0 \mu \mathrm{m}$, depending on the substrate used. Cells occur singly, in pairs, in short chains and in aggregates. Growth occurs at $20-40{ }^{\circ} \mathrm{C}$ and $\mathrm{pH} 5 \cdot 5-8 \cdot 0$, with optimum growth at $37^{\circ} \mathrm{C}$ and $\mathrm{pH} 6 \cdot 5$. Strictly anaerobic. Able to grow on gastric mucin, brain-heart infusion and Columbia media, and on $\mathrm{N}$ acetylglucosamine, $N$-acetylgalactosamine and glucose when these three sugars are in the presence of (each at $2 \mathrm{~g} \mathrm{l}^{-1}$ ) peptone, yeast extract, casitone and tryptone. Cellobiose, lactose, galactose, xylose, fucose, rhamnose, maltose, succinate, acetate, fumarate, butyrate, lactate, casitone, Casamino acids, tryptone, peptone, yeast extract, proline, glycine, aspartate, serine, threonine and glutamate do not support growth. Capable of using mucin as carbon, energy and nitrogen source. Able to release sulfate in a free form from mucin fermentation. In mucin medium, cells are covered with filaments. Growth occurs without vitamins. Colonies appear white with a diameter of $0.7 \mathrm{~mm}$ in soft agar mucin medium.

The type strain is $\mathrm{Muc}^{\mathrm{T}}\left(=\mathrm{ATCC}\right.$ BAA $-835^{\mathrm{T}}=\mathrm{CIP}$ $\left.107961^{\mathrm{T}}\right)$, isolated from the human intestinal tract. Its DNA G $+\mathrm{C}$ content is $47 \cdot 6 \mathrm{~mol} \%$.

\section{Acknowledgements}

The authors are grateful to E. Tosi-Couture (Institut Pasteur, Unité Toxines et Pathogénie bactériennes, Paris, France) for performing the TEM. Dr G. Huet (INSERM, U560, Lille, France) is gratefully acknowledged for the gift of the HT-29 MTX mucin. We thank E. G. 
Zoetendal for discussion and for critically reading the manuscript and H. Smidt for help in the phylogenetic analysis. We thank Professor Dr H. G. Trüper for his help regarding the Latin nomenclature. This work has been carried out with the financial support of the European Community specific RTD programme 'Quality of Life and Management of Living Resources' research project EU \& Microfunction (QKL1-2001-00135). C. M. P. was supported by the Research Council for Earth and Life Sciences (ALW) with financial aid from the Netherlands Organization for Scientific Research (NWO).

\section{References}

Chin, K.-J., Liesack, W. \& Janssen, P. H. (2001). Opitutus terrae gen. nov., sp. nov., to accommodate novel strains of the division 'Verrucomicrobia' isolated from rice paddy soil. Int J Syst Evol Microbiol 51, 1965-1968.

Duncan, S. H., Hold, G. L., Barcenilla, A., Stewart, C. S. \& Flint, H. J. (2002). Roseburia intestinalis sp. nov., a novel saccharolytic, butyrateproducing bacterium from human faeces. Int J Syst Evol Microbiol 52, 1615-1620.

Hedlund, B. P., Gosink, J. J. \& Staley, J. T. (1997). Verrucomicrobia div. nov., a new division of the Bacteria containing three new species of Prosthecobacter. Antonie van Leeuwenhoek 72, 29-38.

Hold, G. L., Pryde, S. E., Russell, V. J., Furrie, E. \& Flint, H. J. (2002). Assessment of microbial diversity in human colonic samples by $16 \mathrm{~S}$ rDNA sequence analysis. FEMS Microbiol Ecol 39, 33-39.

Hooper, L. V. \& Gordon, J. I. (2001). Commensal host-bacterial relationships in the gut. Science 292, 1115-1118.

Hoskins, L. C. \& Boulding, E. T. (1981). Mucin degradation in human colon ecosytems. Evidence for the existence and role of bacterial subpopulations producing glycosidases as extracellular enzymes. J Clin Invest 67, 163-172.

Hugenholtz, P., Goebel, B. M. \& Pace, N. R. (1998). Impact of culture-independent studies on the emerging phylogenetic view of bacterial diversity. J Bacteriol 180, 4765-4774.

Janssen, P. H., Schuhmann, A., Mörschel, E. \& Rainey, F. A. (1997). Novel anaerobic ultramicrobacteria belonging to the Verrucomicrobiales lineage of bacterial descent isolated by dilution culture from anoxic rice paddy soil. Appl Environ Microbiol 63, 1382-1388.

Lane, D. J. (1991). 16S/23S rRNA sequencing. In Nucleic Acid Techniques in Bacterial Systematics, pp. 115-175. Edited by E. Stackebrandt \& M. Goodfellow. Chichester: John Wiley.

Lawson, A. J., On, S. L. W., Logan, J. M. J. \& Stanley, J. (2001). Campylobacter hominis sp. nov., from the human gastrointestinal tract. Int J Syst Evol Microbiol 51, 651-660.

Lesuffleur, T., Barbat, A., Dussaulx, E. \& Zweibaum, A. (1990). Growth adaptation to methotrexate of HT-29 human colon carcinoma cells is associated with their ability to differentiate into columnar absorptive and mucus-secreting cells. Cancer Res 50, 6334-6343.

Mesbah, M., Premachandran, U. \& Whitman, W. B. (1989). Precise measurement of the $\mathrm{G}+\mathrm{C}$ content of deoxyribonucleic acid by highperformance liquid chromatography. Int J Syst Bacteriol 39, 159-167.

Miller, R. S. \& Hoskins, L. C. (1981). Mucin degradation in human colon ecosystems. Fecal population densities of mucindegrading bacteria estimated by a 'most probable number' method. Gastroenterology 81, 759-765.

Muyzer, G., de Waal, E. C. \& Uitterlinden, A. G. (1993). Profiling of complex microbial populations by denaturing gradient gel electrophoresis analysis of polymerase chain reaction-amplified genes coding for 16S rRNA. Appl Environ Microbiol 59, 695-700.

Nübel, U., Engelen, B., Felske, A., Snaidr, J., Wieshuber, A., Amann, R. I., Ludwig, W. \& Backhaus, H. (1996). Sequence heterogeneities of genes encoding 16S rRNAs in Paenibacillus polymyxa detected by temperature gradient gel electrophoresis. J Bacteriol 178, 5636-5643. Plugge, C. M., Zoetendal, E. G. \& Stams, A. J. M. (2000). Caloramator coolhaasii sp. nov., a glutamate-degrading, moderately thermophilic anaerobe. Int J Syst Evol Microbiol 50, 1155-1162.

Ruseler-van Embden, J. G. H., van Lieshout, L. M. C., Gosselink, M. J. \& Marteau, P. (1995). Inability of Lactobacillus casei strain GG, L. acidophilus, and Bifidobacterium bifidum to degrade intestinal mucus glycoproteins. Scand J Gastroenterol 30, 675-680.

Salyers, A. A., West, S. E. H., Vercellotti, J. R. \& Wilkins, T. D. (1977). Fermentation of mucins and plant polysaccharides by anaerobic bacteria from the human colon. Appl Environ Microbiol 34, 529-533.

Salzman, N. H., de Jong, H., Paterson, Y., Harmsen, H. J. M., Welling, G. W. \& Bos, N. A. (2002). Analysis of $16 \mathrm{~S}$ libraries of mouse gastrointestinal microflora reveals a large new group of mouse intestinal bacteria. Microbiology 148, 3651-3660.

Sanguinetti, C. J., Dias Neto, E. \& Simpson, A. J. G. (1994). Rapid silver staining and recovery of PCR products separated on polyacrylamide gels. Biotechniques 17, 914-921.

Schlesner, H. (1987). Verrucomicrobium spinosum gen. nov., sp. nov. a fimbriated prosthecate bacterium. Syst Appl Microbiol 10, 54-56.

Schwiertz, A., Hold, G. L., Duncan, S. H., Gruhl, B., Collins, M. D., Lawson, P. A., Flint, H. J. \& Blaut, M. (2002). Anaerostipes caccae gen. nov., sp. nov., a new saccharolytic, acetate-utilising, butyrateproducing bacterium from human faeces. Syst Appl Microbiol 25, $46-51$.

Simmering, R., Taras, D., Schwiertz, A., Le Blay, G., Gruhl, B., Lawson, P. A., Collins, M. D. \& Blaut, M. (2002). Ruminococcus luti sp. nov., isolated from a human faecal sample. Syst Appl Microbiol 25, 189-193.

Staley, J. T., Bont, J. A. M. \& Jonge, K. (1976). Prosthecobacter fusiformis nov. gen. et sp., the fusiform caulobacter. Antonie van Leeuwenhoek 42, 333-342.

Stams, A. J. M., van Dijk, J. B., Dijkema, C. \& Plugge, C. M. (1993). Growth of syntrophic propionate-oxidizing bacteria with fumarate in the absence of methanogenic bacteria. Appl Environ Microbiol 59, 1114-1119.

Strunk, O. \& Ludwig, W. (1995). ARB - a software environment for sequence data. Department of Microbiology, Technical University of Munich, Munich, Germany (http://www.arb-home.de/).

Suau, A., Bonnet, R., Sutren, M., Godon, J.-J., Gibson, G. R., Collins, M. D. \& Doré, J. (1999). Direct analysis of genes encoding $16 \mathrm{~S}$ rRNA from complex communities reveals many novel molecular species within the human gut. Appl Environ Microbiol 65, 4799-4807.

Taras, D., Simmering, R., Collins, M. D., Lawson, P. A. \& Blaut, M. (2002). Reclassification of Eubacterium formicigenerans Holdeman and Moore 1974 as Dorea formicigenerans gen. nov., comb. nov., and description of Dorea longicatena sp. nov., isolated from human faeces. Int J Syst Evol Microbiol 52, 423-428.

Vaughan, E. E., Schut, F., Heilig, H. G. H. J., Zoetendal, E. G., de Vos, W. M. \& Akkermans, A. D. L. (2000). A molecular view of the intestinal ecosystem. Curr Issues Intest Microbiol 1, 1-12.

Willis, C. L., Cummings, J. H., Neale, G. \& Gibson, G. R. (1996). In vitro effects of mucin fermentation on the growth of human colonic sulphate-reducing bacteria. Anaerobe 2, 117-122.

Wilson, K. H. \& Blitchington, R. B. (1996). Human colonic biota studied by ribosomal DNA sequence analysis. Appl Environ Microbiol 62, 2273-2278.

Zhou, J. S., Gopal, P. K. \& Gill, H. S. (2001). Potential probiotic lactic acid bacteria Lactobacillus rhamnosus (HN001), Lactobacillus acidophilus (HN017) and Bifidobacterium lactis (HN019) do not degrade gastric mucin in vitro. Int J Food Microbiol 63, 81-90. 
Zoetendal, E. G., Akkermans, A. D. L. \& de Vos, W. M. (1998). Temperature gradient gel electrophoresis analysis of 16S rRNA from human fecal samples reveals stable and host-specific communities of active bacteria. Appl Environ Microbiol 64, 3854-3859.
Zoetendal, E. G., Plugge, C. M., Akkermans, A. D. L. \& de Vos, W. M. (2003). Victivallis vadensis gen. nov., sp. nov., a sugarfermenting anaerobe from human faeces. Int J Syst Evol Microbiol 53, 211-215. 